\title{
PENINGKATAN AKTIVITAS DAN KREATIVITAS BELAJAR GEOGRAFI \\ MATERI PENGINDERAAN JAUH DENGAN MENGGUNAKAN MODEL DISCOVERY LEARNING PADA SISWA KELAS X IPS 1 SMA NEGERI 1 SAKRA TIMUR TAHUN PELAJARAN 2020/2021
}

\author{
Ikhtiqlal Irpan Ahadi \\ SMA NEGERI 1 SAKRA TIMUR \\ Email : irpanahadi@gmail.com
}

\begin{abstract}
ABSTRAK
Penelitian ini ditujukan untuk mengetahui seberapa besar peningkatan aktivitas belajar dan krestivitas belajar siswa setelah diterapkan model discovery learning pada mata pelajaran geografi materi penginderaan jauh kelas X IPS 1 SMA Negeri 1 Sakra Timur. Penelitian ini merupakan jenis penelitian tindakan kelas, dengan metode pembelajaran yang diterapkan adalah metode diskusi, tanya jawab dan kajian pustaka. Subjek penelitian adalah siswa kelas X IPS 1 SMA Negeri 1 Sakra Timur tahun pelajaran 2020/2021 yang berjumlah sebanyak 30 orang siswa. Kegiatan penelitian ini dilaksanakan sebanya dua siklus, tiap siklus terdiri dari tahap perencanaan, tindakan, observasi, dan refleksi, yang bertujuan untuk mmperbaiki kualitas pembelajaran. Alat pengumpulan data menggunakan lembar pengamatan aktivitas belajar, lembar pengamatan kreativitas belajar dan test hasil belajar yang berupa soal-soal uraian. Data dari hasil observasi test formatif disetiap siklus menjadi dasar atau bahan perbaikan untuk siklus berikutnya. Hasil penelitian menunjukkan bahwa : terdapat peningkatan aktivitas belajar dan kreativitas belajar siswa yang terlihat dari peningkatan hasil belajar siswa disetiap siklus setelah menggunakan model discovery learning pada pembelajaran geografi materi penginderaan jauh kelas X IPS 1 SMA Negeri 1 Sakra Timur tahun pelajaran 2020/2021.
\end{abstract}

Kata kunci : aktivitas belajar, krestivitas belajar, dicovery learning

\begin{abstract}
This study was aimed to find out how much the increase in student learning activities and creativity after the discovery learning model was applied to remote sensing subjects in geography class X IPS 1 SMA Negeri 1 Sakra Timur. This research is a type of classroom action research, with the learning method applied is the method of discussion, question and answer and literature review. The research subjects were students of class X IPS 1 SMA Negeri 1 Sakra Timur in the academic year 2020/2021, totaling 30 students. This research activity was carried out in two cycles, each cycle consisting of stages of planning, action, observation, and reflection, which aims to improve the quality of learning. The data collection tool uses learning activity observation sheets, learning creativity observation sheets and learning outcomes tests in the form of description questions. Data from the results of formative test observations in each cycle became the basis or material for improvement for the next cycle. The results showed that: there was an increase in student learning activities and creativity as seen from the increase in student learning outcomes in each cycle after using the discovery learning model in learning geography for remote sensing material for class $\mathrm{X}$ IPS 1 SMA Negeri 1 Sakra Timur in the academic year 2020/2021.
\end{abstract}

Keywords: learning activities, learning creativity, discovery learning 


\section{PENDAHULUAN}

Dalam penyelenggaraan proses belajar mengajar pada umumnya, sering dilakukan secara klasikal dimana seluruh siswa dalam kelas dipandang sebagai suatu kelompok besar yang acapkali cara-cara mengajar tidak disesuaikan dengan kemampuan rata-rata siswa. Padahal kegiatan belajar mengajar adalah suatu proses intraksi atau hubungan timbal balik antara guru dan siswa dalam proses pembelajaran. Masalah pendidikan tidak bisa lepas dari masalah pembelajaran, karena pembelajaran merupakan inti dari proses peningkatan kualitas pendidikan. Keefektifan pembelajaran dapat tergambar dari hasil belajar yang dicapai siswa. Dengan kata lain makin efektif pembelajaran yang dilaksanakan, maka makin meningkat dan baik hasil belajar siswa.

Berhasilnya tujuan pembelajaran juga ditentukan oleh banyak faktor, diantaranya adalah faktor guru atau pendidik dalam melaksanakan proses belajar mengajar, karena guru secara langsung dapat mempengaruhi, membina dan meningkatkan kecerdasan serta keterampilan siswa. Untuk mencapai tujuan pembelajaran secara maksimal, peran guru sangat penting dan diharapkan guru memiliki model atau strategi mengajar yang baik dan mampu memilih model dan metode pembelajaran yang tepat sesuai dengan konsep-konsep mata pelajaran yang akan disampaikan. Kemampuan guru dalam memilih model dan metode pembelajaran serta menerapkannya dalam kegiatan pembelajaran turut mempengaruhi keberhasilan siswa dalam pembelajaran. Sebagaimana yang telah dijelaskan dalam Peraturan Mentri Pendidikan dan Kebudayaan No. 41 Tahun 2007 pasal 1 ayat 1 tentang standar proses, bahwa standar proses pendidikan untuk satuan pendidikan dasar dan menengah mencakup perencanaan proses pembelajaran, pelaksanaan proses pembelajaran, penilaian hasil pembelajaran, dan pengawasan proses pembelajaran.

Mata pelajaran geografi bertujuan agar siswa memiliki kemampuan membangun dan mengembangkan pemahaman siswa tentang variasi dan oeganisasi spasial masyarakat, tempat dan lingkungan pada muka bumi. Siswa didorong untuk memahami aspek dan proses fisik yang membentuk pola bumi, karakteristik dan persebaran spasial ekologis dipermukaan bumi. Selain itu siswa dimotivasi secara aktif dan kreatif untuk menelaah bahwa kebudayaan dan pengalaman mempengaruhi persepsi manusia tentang tempat dan wilayah. Pengetahuan keterampilan dan nilai-nilai yang diperoleh dalam mata pelajaran geografi diharapkan dapat membangun kemampuan siswa untuk bersikap, bertindak cerdas, arif dan bertanggung jawab dalam menghadapi masalah sosial, ekonomi dan ekologis.

Permendiknas No. 22 Tahun 2006 menjelaskan bahwa, didalam materi pelajaran geografi tersirat nilai-nilai sebagai berikut : (1) pemahaman pola spasial, lingkungan dan kewilayahan serta proses yang berkaitan, (2) penguasaan keterampilan dasar dalam memperoleh data dan informasi, mengkomunikasikan dan menerapkan pengetahuan geografi, (3) menampilkan prilaku peduli terhadap lingkungan hidup dan memanfaatkan sumber daya alam secara arif serta memiliki toleransi terhadap keragaman budaya masyarakat.

Berdasarkan uraian di atas maka seharusnya pembelajaran geografi di sekolah merupakan suatu kegiatan pembelajaran yang disenangi, menantang dan mempunyai makna tersendiri bagi siswa. Namun selama ini sering terjadi di sekolah termasuk di SMA Negeri 1 Sakra Timur, pembelajaran geografi kurang kami kemas dengan model dan metode pembelajaran yang menarik, menantang dan menyenangkan, sehingga pembelajaran cendrung membosankan dan pada akhirnya menyebabkan pembelajaran geografi menjadi kurang efektif.

Dari hasil pengamatan yang kami lakukan dan data yang ada, diketahui bahwa minat belajar siswa kelas X IPS 1 di SMA Negeri 1 Sakra Timur saat mengikuti pelajaran geografi termasuk rendah. Indikasi rendahnya minat tersebut diketahui dari rendahnya hasil belajar setelah dilakukan evaluasi ulangan harian, hal ini disebabkan selama ini kami masih sering menggunakan model dan metode pembelajaran yang konvensional yaitu ceramah saja, sehingga pelajaran geografi menjadi kurang menarik. Hal ini membuat siswa mudah melupakan pokok bahasan pada saat itu. Selain itu metode pembelajaran yang digunakan membuat siswa tidak 
bekerja secara maksimal, guru saja yang memberikan materi sedangkan siswa hanya duduk dan mendengarkan penjelasan dari guru.

Belajar merupakan bagian dari aktivitas. Tidak ada belajar kalau tidak ada aktifitas. Aktivitas siswa dalam kegiatan pembelajaran tidak hanya mendengarkan dan mencatat saja. Aktivitas belajar harus dilakukan siswa sebagai usaha untuk meningkatkan hasil belajar. Seiring dengan itu (Djamarah, 2000 : 67) menyatakan bahwa belajar sambil melakukan aktivitas lebih banyak mendatangkan hasil bagi anak didik, sebab kesan yang didapatkan oleh anak didik lebih tahan lama dan tersimpan didalam benak anak didik. Aktivitas belajar adalah segala kegiatan belajar siswa yang menghasilkan suatu perubahan khas, yaitu hasil belajar yang akan nampak melalui prestasi belajar yang akan dicapai, (Sudjana, 1982 : 48). Aktivitas siswa merupakan kegiatan atau prilaku yang terjadi selma proses belajar mengajar. Aktivitas-aktivitas yang dimaksud dalam kegiatan pembelajaran adalah kegiatan aktivitas siswa yang mengarah pada proses belajar mengajar. Aktivitas tersebut dibagi menjadi dua antara lain : (1) aktivitas on task, yaitu aktivitas yang relevan dengan pembelajaran seperti bertanya kepada guru, dapat menjawab pertanyaan guru, menjawab pertanyaan teman, memberikan pendapat dalam diskusi, menyelesaikan tugas dari guru, dan ketepatan dalam mengumpulkan tugas dari guru. (2) aktivitas off task, yaitu aktivitas yang tidak relevan dengan pembelajaran seperti ngobrol, mengganggu teman, keluar masuk kelas, melamun dan bermain-main.

Kreativitas adalah kemampuan yang mencerminkan kelancaran, keluwesan, dan orasinalitas dalam berfikir serta kemampuan untuk mengelaborasi suatu gagasan. Pengembangan kratifitas dapat dilakukan melalui proses belajar discovery/ inquiri dan belajar bermakna, dan tidak dapat dilakukan hanya dengan kegiatan belajar ekspositori. Karena inti dari kreatifitas adalah pengembangan kemampuan proses berfikir dengan cara melihat suatu masalah dari berbagai sudut pandang, atau menguraikan suatu masalah atas beberapa kemungkinan pemecahan. Untuk mengembangkan kemampuan yang demikian guru perlu mengembangkan situasi pembelajaran yang banyak memberikan kesempatan kepada siswa untuk memecahkan masalah, melakukan beberapa percobaan, mengembangkan gagasan atau konsepkonsep siswa sendiri. Situasi yang demikian menuntut pula sikap demokratis, terbuka, bersahabat dan percaya kepada siswa. Belajar kreativ dapat diartikan sebagai kemampuan siswa enciptakan hal-hal baru dalam belajarnya baik berupa kemampuan mengembangkan informasi yang diperoleh dari guru dalam proses belajar mengajar yang berupa pengetahuan sehingga dapat membuat kombinasi yang baru dalam belajarnya dengan indikator : (1) memiliki rasa ingin tahu yang besar, (2) kaya akan pemikiran/ imajinatif, (3) memiliki motivasi tinggi, (4) berani mengambil resiko, (5) memiliki sifat menghargai/ toleransi.

Model pembelajaran dapat diartikan sebagai kerangka koseptual yang melukiskan prosedur yang sistimatis dalam mengorganisasikan pengalaman belajar untuk tujan belajar tertentu, (Aunurrahman, 2009 : 146). Model discovery learning adalah model mengajar yang mengatur pengajaran sedemikian rupa sehingga anak memperoleh pengetahuan yang sebelumnya belum diketahuinya itu tidak melalui pemberitahuan, sebagian atau seluruhnya ditemukan sendiri. Penggunaan model discovery learning, ingin merubah kondisi belajar yang fasip menjadi aktif dan kreatif. Merubah pembelajaran yang teacher oriented ke student oriented. Merubah modus ekspository, siswa hanya menerima informasi secara keseluruhan dari guru ke modus discovery, siswa menemukan informasi sendiri. Tiga ciri uatam belajar penemuan (discovery learning) yaitu : (1) mengeksplorasi dan memecahkan masalah untuk menciptakan, menggabungkan dan menggeneralisasi pengetahuan, (2) berpusat pada siswa, (3) kegiatan untuk menggabungkan pengetahuan baru dengan pengetahuan yang sudah ada.

Model discovery learning menempatkan guru sebagai fasilitator. Guru membimbing siswa dimana diperlukan. Dalam model ini, siswa didorong untuk berpikir sendiri, menganalisis sendiri sehingga dapat menemukan prinsip umum 
berdasarkan bahan atau data yang telah disajikan oleh guru, (PPPG : 2004 : 4 dalam Riensuciati, 2003). Penelitian ini bertujuan untuk menganalisis peningkatan aktivitas dan kreativitas belajar geografi materi penginderaan jauh kelas X IPS 1 SMA Negeri 1 Sakra Timur dengan menggunakan discovery learning.

\section{METODE PENELITIAN}

Penelitian ini adalah penelitian tindakan kelas (PTK). Penelitian tindakan kelas merupakan suatu penelitian yang dilakukan oleh guru berdasarkan permasalahan yang dihadapinya di kelas dengan mengunakan prosedur siklus (perencanaan, tindakan, observasi, dan refleksi) yang bertujuan untuk memperbaiki kualitas pembelajaran baik terkait sistem, cara kerja, proses, isi (kurikulum), kompetensi, alat/ media, evaluasi, situasi dan sebagainya. Dengan harapan dapat meningkatkan kualitas output, outcome, siswa dan kinerja guru, (Pargito, 2011 : 19). Empat tahapan penelitian tindakat kelas tersebut sebagai berikut : (1) tahap perencanaan yaitu penjelasan tentang apa, mengapa, kapan, dimana, oleh siapa, dan bagaimana tindakan tersebut dilakukan, (2) tahap pelaksanaan yaitu merupakan implementasi atau penerapan isi rancangan dengan menggunakan tindakan kelas, (3) tahap pengamatan yaitu kegiatan pengamatan yang dilakukan oleh guru, (4) tahap refleksi yaitu merupakan kegiatan untuk mengemukakan kembali apa yang sudah dilakukan, Suharsini (Arikunto, 2010 : 17). Siklus akan terus dilakukan sampai ditemukan tindakan atau hasil yang ideal atau yang dianggap ideal. Banyak siklus tergantung kepuasan peneliti, namun sebaiknya tidak kurang dari dua siklus, (Suhardjono, 2011 : 75).

Setting tindakan menjelaskan kondisi aktual atau kondisi riil tentang keadaan subjek tindakan. Sebagaimana diketahui bahwa penelitian tindakan merupakan kegiatan untuk menigkatkan kemampuan subjek tindakan secara tepat. Setting dan saubjek tindakan dalam penelitian ini adalah : (a) Lokasi penelitian dilaksanakan di SMA Negeri 1 Sakra Timur, (b) Subjek dan objek penelitian, subjek tindakan yang akan ditingkatkan kemampuannya adalah siswa kelas X IPS 1 yang berjumlah 30 orang, objek dalam penelitian ini adalah : 1) aktifvtas belajar siswa dan kreativitas belajar siswa, 2) penggunaan model discovery learning, (c) Karakteristik subjek, karakteristik kelompok subjek tindakan yaitu 17 orang siswa memiliki kemampaun menginterpretasi citra penginderaan jauh sangat rendah, (d) Waktu penelitian, penelitian ini dilaksanakan pada semester ganjil tahun 2020/2021.

\section{HASIL DAN PEMBAHASAN}

Penelitian ini menjawab pertanyaan berupa peningkatan aktivitas dan kreativitas belajar geografi materi penginderaan jauh siswa kelas $\mathrm{X}$ IPS 1 SMA Negeri 1 Sakra Timur sebagai berikut :

1. Peningkatan aktivitas belajar geografi materi penginderaan jauh dengan menggunakan model discovery learning.

Terjadi peningkatan aktivitas belajar siswa dengan menggunakan model discovery learning, yang ditunjukkan dengan peningkatan aktivitas on task (aktivitas yang relevan dengan pembelajaran) dan penurunan aktivitas off task (aktivitas yang tidak relevan dengan pembelajaran) disetiap siklus. Pada siklus I sebesar $67,3 \%$ pada aktivitas on task dan $32,7 \%$ pada off task dengan kategori sedang. Pada siklus II peningkatan on task menjadi 78,6\% dan penurunan aktivitas off task menjadi $21,4 \%$ dengan kategori tinggi. Dengan demikian ada peningkatan yang signifikan, hal ini berarti siswa sudah mempunyai aktivitas on task yang sangat baik. Pada akhir siklus II ratarata nilai aktifitas yaitu bertanya kepada fasilitator, bertanya kepada teman, menjawab pertanyaan fasilitator, menjawab pertanyaan teman, memberi pendapat dalam diskusi, menyelesaikan tugas yang diberikan oleh fasilitator, ketepatan mengumpulkan tugas telah mencapai indikator yang diharapkan yaitu $\geq 75$.

Peningkatan kreatifitas belajar geografi materi penginderaan jauh dengan 
menggunakan model discovery learning. Perningkatan kreativitas belajar siswa dengan menggunakan model discovery learning, dapat diketahui perkembangannya melalui lima indikator kreativitas belajar siswa yaitu : (1) rasa ingin tahu, (2) kaya akan pemikiran, (3) motivasi tinggi, (4) berani mengambil resiko, (5) toleransi/ menghargai pendapat orang lain ditiap siklusnya. Pada siklus I sebesar 67,3\% dengan kategori sedang. Pada siklus II terjadi peningkatan kreativitas belajar siswa menjadi $78.6 \%$ dengan kategori tinggi. Dengan demikian ada peningkatan signifikan, hal ini berarti sswa sudah mempunyai kreativitas yang sangat baik.

2. Peningkatan hasil belajar geografi materi penginderaan jauh dengan menggunakan model discovery learning.

Hasil belajar siswa dapat diketahui perkembangannya melalui data hasil penelitian sebagai berikut, rata-rata nilai siswa kelas $\mathrm{X}$ IPS 1 sebelum menggunakan model discovery learning sebesar 63,0 dengan siswa yang tuntas hanya 8 orang dari 30 orang siswa, atau hanya $26,7 \%$. Kemudian setelah proses pembelajaran dengan model discovery learning, maka nilai rata-rata kelas X IPS 1 pada siklus I meningkat menjadi 71,0 dengan peserta didik yang tuntas meningkat menjadi 17 siswa atau 56,7\%, dan peningkatan tingkat ketuntasan dari prasiklus ke siklus I sebesar 30\%. Hal ini menunjukkan bahwa kemampuan siswa dalam pembelajaran belum maksimal. Pada siklus II didapat nilai rata-rata kelas 76,2 dengan siswa tuntas sebesar 26 siswa atau sebesar $86,7 \%$, dan peningkatan tingkat ketuntasan dari siklus I ke siklus II sebesar 30\% dengan demikian ada peningkatan yang signifikan, hal ini disebabkan oleh sudah mulai mengerti strategi pembelajaran yang diberikan oleh guru.

\section{SIMPULAN DAN SARAN}

Berdasarkan hasil analisis dan pembahasan dalam pelaksanaan penilaian tindakan kelas di kelas X IPS 1 SMA Negeri 1 Sakra Timur tahun pelajaran 2020/2021 dapat disimpulkan sebagai berikut ; Aktivitas belajar siswa yang terdiri dari dua aktivitas yaitu on tast (aktivitas yang relevan dengan pembelajaran) dan aktivitas off task (aktivitas yang tidak relevan dengan pembelajaran) mengalami peningkatan setelah menggunakan discovery learning, hal ini ditunjukkan dengan peningkatan indikator on task (aktivitas yang relevan dengan pembelajaran) ditiap siklus dan penurunan aktifitas off task (aktivitas yang tidak relevan dengan pembelajaran) setelah penggunaan model discovery learning. Dengan demikian melalui penggunaan model discovery learning yang dilaksanakan sebanya dua siklus terbukti dapat meningkatkan aktivitas belajar siswa.

Kreativitas belajar siswa yang terdiri dari lima indikator yakni (1) rasa ingin tahu, (2) kaya akan pemikiran/ ide, (3) motivasi tinggi, (4) berani mengambil resiko, (5) toleransi/ menghargai, mengalami peningkatan setelah menggunakan model discovery learning, hal ini ditunjukkan dengan peningkatan indikator kreativitas disetiap siklus, dan siswa mulai terlatih bersikap kreatif dalam belajar. Dengan demikian melalui penggunaan model discovery learning yang laksanakan sebanyak dua sikkus terbukti dapat meningkatkan kreativitas belajar siswa.

Hasil belajar siswa mengalami peningkatan setelah penggunaan model discovery learning, hal ini dapat diketahui perkembangannya setelah dilakukan evaluasi belajar dan terlihat dari peningkatan rata-rata perolehan nilai hasil belajar siswa disetiap siklus. Dengan demikian penggunaan model discovery learning terbukti dapat meningkatkan hasil belajar siswa.

\section{DAFTAR PUSTAKA}

Arikunto, Suharsini. 2006. Penelitian Tindakan Kelas, Suatu Pengantar Praktis. Jakarta : Bitama Aksara.

Asrori, Mohammad. 2007. Psikologi Pembelajaran. Bandung: Wacana Prima.

Depdiknas. 2006. Kurikulum Geografi SMA. Bahan Sosialisasi Kurikulum Berbasis Kompetensi.

Djamarah, Saiful Bahri. 2000. Guru dan Anak Didik Dalam Intraksi Edukatif. Jakarta : 


\section{Rineka Cipta}

Permendiknas Nomor 22. 2006. Standar Isi. Jakarta : Kemendikbud

Permendiknas Nomor 41.2007. Standar Proses. Jakarta : Kemendikbud

Sudjana, Nana. 1982. Cara Belajar Siswa Aktif. Bandung : Sinar Baru

Sukidin, Basrowi, Suranto. 2008. Manajemen Penelitian Tindakan Kelas. Jakarta : Insan Cendikia. 